\title{
Predicting long-term absenteeism from work in construction industry: a longitudinal study
}

\author{
Peter Hoonakker ${ }^{\mathrm{a}}$ and Cor van Duivenbooden ${ }^{\mathrm{b}}$ \\ ${ }^{a}$ Center for Quality and Productivity Improvement, University of Wisconsin-Madison, 3128 Engineering Centers \\ Building, 1550 Engineering Drive, Madison, WI 53706, USA \\ ${ }^{\mathrm{b}}$ Arbouw, Dutch National Institute for Safety and Health in the Construction Industry, Postbus 213 \\ 3840 AE Harderwijk, The Netherlands
}

\begin{abstract}
In this study we examine whether the Work Ability Index (WAI) has additional value in predicting long-term absenteeism in construction industry. Results of the study show that the WAI has additional value in predicting absenteeism, but that the amount of explained variance is low. This is partly due to the definition of absenteeism in The Netherlands, where this study took place.
\end{abstract}

Keywords: Construction industry, work ability, absenteeism

\section{Introduction}

Physically demanding jobs are characterized by reduced work ability, increased sick leave and early retirement [1]. Construction industry is an example of industries that are characterized by physically demanding jobs, musculoskeletal diseases, a high number of injuries, high absenteeism from work and high disability. For example, results of a survey among Finish construction workers showed that more than half of the respondents older than 45 reported that their work ability was at least slightly reduced [2]. However, there are few methods available to predict absenteeism and disability. If we would be able to identify and monitor workers who have higher chance to develop injuries and diseases and the associated absenteeism, we could take preventive action, for example using socio-technical methods such as task rotation, job enlargement, etc. to reduce the workload of workers at high risk. One of the instruments that seems to be successful in predicting reduced workability, absenteeism and disability is the Work Ability Index (WAI), developed by Ilmarinen et al. [3]. The WAI consists of 7 items which are used to create a sum score (Table 1).
Table 1

Work Ability Index

\begin{tabular}{|c|c|c|}
\hline Topic & Score & Description \\
\hline 1. Current work ability & $0-10$ & $\begin{array}{l}0=\text { very poor } \\
10=\text { very good }\end{array}$ \\
\hline $\begin{array}{l}\text { 2. Current physical and psy- } \\
\text { cho-social work demands }\end{array}$ & $2-10$ & $\begin{array}{l}2=\text { very poor } \\
10=\text { very good }\end{array}$ \\
\hline $\begin{array}{l}\text { 3. Current medical symptoms, } \\
\text { conditions, and injuries }\end{array}$ & $1-7$ & $\begin{array}{l}1=5 \text { or more } \\
7=\text { none }\end{array}$ \\
\hline $\begin{array}{l}\text { 4. Limitations in current job } \\
\text { caused by medical symp- } \\
\text { toms, conditions and injuries }\end{array}$ & $1-6$ & $\begin{array}{l}1=\text { fully impaired } \\
6=\text { no impairment }\end{array}$ \\
\hline $\begin{array}{l}\text { 5. Sickness absenteeism in the } \\
\text { last } 12 \text { months }\end{array}$ & $1-5$ & $\begin{array}{l}1=100 \text { days or more } \\
5=\text { zero }\end{array}$ \\
\hline $\begin{array}{l}\text { 6. Future expectation about } \\
\text { work ability }\end{array}$ & $1,4,7$ & $\begin{array}{l}1=\text { disabled } \\
4=\text { not sure } \\
7=\text { being able }\end{array}$ \\
\hline 7. Mental capacities & $1-4$ & $\begin{array}{l}1=\text { very poor } \\
4=\text { very good }\end{array}$ \\
\hline Total & $7-49$ & $\begin{array}{l}\text { Poor }=7-27 \\
\text { Moderate }=28-36 \\
\text { Good }=37-43 \\
\text { Excellent }=44-49\end{array}$ \\
\hline
\end{tabular}

In the Netherlands, working conditions and health of construction workers are monitored on a regular basis in a Periodic Occupational Health Survey (POHS) that consists of a medical examination and a questionnaire. Since 2005, the WAI has become part of the questionnaire. The purpose of this study is to 
examine if the WAI can predict long-term absenteeism, above and beyond the information already collected in the POHS.

\section{Methods}

\subsection{Sample}

Every five years, construction workers in The Netherlands have the opportunity to undergo a (free) Periodic Occupational Health Survey (POHS) [4]. Every year $\sim 30,000$ construction workers (blue and white collar) take part in the POHS. In this study the sample that had their physical examination and filled out the questionnaire in 2005 is used. Absenteeism data was collected for the period 2006-2009. The combined, longitudinal database contains data of 8,423 respondents (see Figure 1). Seventy-eight percent of the longitudinal sample is work site personnel (blue collar workers, $\mathrm{N}=6,543$ ) and $22 \%$ of the sample are construction site managers, construction firm owners, managers and technical and administrative personnel (office or white collar workers, $\mathrm{N}=1880$ ). The respondents varied in age from 16 to 63 years. Average age of the sample was 44 years.

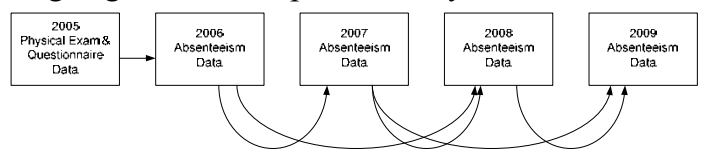

Figure 1 Longitudinal sample 1993-1998

\subsection{Physical examination}

The physical examination consists of various tests. The tests that will be used in this study are: the Forced Expiratory Volume, a measure of the lung function, and the risk of a cardiac event, based on the Framingham score. In addition, length and weight will be used to calculate the Body Mass Index (BMI).

\subsection{Questionnaire}

The Periodic Occupational Health Survey Questionnaire (POHSQ) consists of two parts. The first part consists of a total of 42 health questions about lifestyle (alcohol use, smoking and exercising) impairments and diseases, recent medical treatment, and a self-reported assessment about the workrelatedness of health complaints. Examples of some of the questions are: "Do you regularly have pain or stiffness in your neck? (y/n)" "Do you regularly have pain or stiffness in your back (y/n)"?, "Do you regularly have pain or stiffness in your upper limbs? $(\mathrm{y} / \mathrm{n})$ ", and "Did you, in the last 5 years, receive medical treatment for persistent back or neck complaints"? In the second part of POHSQ, 42 questions are asked about various experiences in the work situation. It covers descriptions and complaints about working postures, physical exertion, mental workload and stress, and physical and chemical hazards. In this study we use questions about physical demands (e.g. Are you, at your work, often bothered by working in the same posture for a long time? Is your work physically demanding?, etc.); and psycho-social demands (e.g. Is your work mentally very demanding? Do you have to concentrate strongly at your work? Does your work require great precision? Do you regularly work under time pressure?).

\subsection{Absenteeism data}

Absenteeism data was collected for the 4 years after POHS survey 2006-2009). Totally, the 8,423 were 421,773 days absent from their work in those 4 years. Note that absenteeism from work in The Netherlands is not restricted to work-related absenteeism. All absenteeism, including for example absenteeism as result of an accident at home or on vacation is registered as absenteeism from work. We constructed several absenteeism measures: frequency, duration: (short term absenteeism (less than 7 days); mid term absenteeism (8-42 days) and long-term absenteeism (more than 42 days). However, we are interested in predicting long-term absenteeism. Therefore we use a single measure: Have the respondents been absent for more than 42 days in those 4 years?

\subsection{Analysis}

Descriptive statistics were used to describe work characteristics and absenteeism of the sample. Logistical regression analysis was used to examine the effects of age, life style variables, biometrics, job characteristics (physical and psycho-social demands), health complaints, and the WAI score on long-term absenteeism in a stepwise procedure.

\section{Results}

\subsection{Descriptive statistics}

In this section we provide the descriptive statistics of the POHS and absenteeism data. 
Table 2

Personal and Job characteristics

\begin{tabular}{l|c}
\hline Factor & $\%$ \\
\hline Individual characteristics & \\
$\quad$ Age (average in years) & 44,2 \\
Occupational characteristics & \\
$\quad$ Blue collar (vs. White collar)) & $78 \%$ \\
Life Style & \\
Problematic alcohol consumption & $17 \%$ \\
(>15 glasses a week) & \\
Inordinate alcohol consumption & $2.4 \%$ \\
(> 35 glasses a week) & \\
Smoker (Y) & $33 \%$ \\
Sufficient physical activities (Y) & $55 \%$ \\
Sufficient physical effort (Y) & $21 \%$ \\
Physical Workload & \\
Lifting, pushing or pulling (Y) & $48 \%$ \\
Awkward postures (Y) & $25 \%$ \\
Static workload (Y) & $37 \%$ \\
Whole body vibrations (Y) & $15 \%$ \\
Hand-arm vibrations (Y) & $17 \%$ \\
Repetitive Movements (Y) & $22 \%$ \\
Psychosociale workload & \\
Time pressure (Y) & $59 \%$ \\
Lack of autonomy (Y) & $35 \%$ \\
Lack of job satisfaction (Y) & $5 \%$ \\
Lack of supervisory support (Y) & $13 \%$ \\
\hline
\end{tabular}

Results in Table 2 show that many of the construction workers $(79 \%)$ are not fit according to the Dutch fit norm. Further, many respondents report a high physical workload (lifting, pulling, and pushing (48\%) and static workload (37\%)) as well as psychosocial workload, especially working under time pressure (59\%).

Table 3

Health complaints

\begin{tabular}{l|c}
\hline Health Complaints & $\%$ \\
\cline { 1 - 2 } Musculo-skeletal disorders & 68 \\
Chest pain & $9 \%$ \\
Stress reactions & 38 \\
Psychological complaints & $\%$ \\
Respiratory complaints & 10 \\
Depression & $\%$ \\
& 11 \\
& $\%$ \\
& 10 \\
\hline
\end{tabular}

Results in Table 3 show that many of the construction workers in the sample report health complaints. Most of the complaints concern musculoskeletal disorders.
Table 4

Work Ability Index

\begin{tabular}{l|c}
\hline WAI category & $\%$ \\
\hline Poor & $2.5 \%$ \\
Moderate & $18.0 \%$ \\
Good & $49.1 \%$ \\
Excellent & $30.4 \%$ \\
\hline Total & $100 \%$ \\
\hline
\end{tabular}

The work ability index (WAI) of most of the respondents is either excellent (30\%) or good (49\%). However, $18 \%$ of respondents report moderate and $3 \%$ poor workability.

Table 5

Biometrics

\begin{tabular}{l|c}
\hline COPD category & Percentage \\
\hline Normal & $90.5 \%$ \\
Mild & $6.6 \%$ \\
Moderate & $3.6 \%$ \\
Serious & $0.3 \%$ \\
\hline Total & $\mathbf{1 0 0 \%}$ \\
\hline
\end{tabular}

Nearly $10 \%$ of the sample suffers from Chronic Obstructive Pulmonary Disease (COPD) based on their FEV1/FVC ratio, ranging from mild $(6.6 \%)$ to serious $(0.3 \%)$.

Table 6

Frequency of absenteeism 2005-2009

\begin{tabular}{l|cccc|c}
\hline & 2006 & 2007 & 2008 & 2009 & $\begin{array}{c}2006- \\
2009\end{array}$ \\
\hline $\begin{array}{l}\text { Number of em- } \\
\text { ployees with zero } \\
\text { absenteeism in a } \\
\text { year (\%) }\end{array}$ & $\begin{array}{c}5857 \\
(70 \%)\end{array}$ & $\begin{array}{c}6151 \\
(73 \%)\end{array}$ & $\begin{array}{c}6555 \\
(78 \%)\end{array}$ & $\begin{array}{l}6770 \\
(80 \%)\end{array}$ & $\begin{array}{c}4200 \\
(50 \%)\end{array}$ \\
$\begin{array}{l}\text { Average number } \\
\text { of times sick per }\end{array}$ & 0.44 & 0.39 & 0.32 & 0.28 & 1.42 \\
$\begin{array}{l}\text { employee, per year } \\
\text { (SD) }\end{array}$ & $(0.77)$ & $(0.75)$ & $(0.68)$ & $(0.64)$ & $(2.09)$ \\
$\begin{array}{l}\text { Maximum num- } \\
\text { ber of times sick } \\
\text { per year }\end{array}$ & 6 & 5 & 6 & 5 & 17 \\
\hline
\end{tabular}

Most of the respondents (70-80\%) never report sick in a given year. Half of the respondents $(50 \%)$ have reported sick in the 4-year period. Totally, respondents reported 421,773 days of absenteeism. When the respondents report sick, on average this lasts about 10 days. However, most of absenteeism is shorter than 7 days, and only a small percentage (14\%) of respondents reports long-term absenteeism (more than 42 days). However, this small percentage makes up for $91 \%$ of total days of absenteeism. 
Table 7: Relation between WAI and absenteeism

\begin{tabular}{|c|c|c|}
\hline & \multicolumn{2}{|c|}{ Long-term absenteeism in 2006-2009 } \\
\hline Workability & $\begin{array}{c}\text { Yes } \\
(\mathrm{N}=1608)\end{array}$ & $\begin{array}{c}\text { No } \\
(\mathrm{N}=6815)\end{array}$ \\
\hline $\operatorname{Bad}(N=207)$ & $31 \%$ & $69 \%$ \\
\hline Moderate $(\mathrm{N}=1514)$ & $33 \%$ & $67 \%$ \\
\hline Good $(\mathrm{N}=4134)$ & $27 \%$ & $73 \%$ \\
\hline Excellent $(\mathrm{N}=2563)$ & $20 \%$ & $80 \%$ \\
\hline Total $(\mathrm{N}=\mathbf{8 4 2 3})$ & $26 \%$ & $74 \%$ \\
\hline
\end{tabular}

\subsection{Logistical regression analysis}

There is a significant relation between WAI and frequency of absenteeism $\left(\chi^{2}=97.2, d f=3, \mathrm{p}<0.001\right)$. Respondents with excellent or good workability report significantly less long-term absenteeism. However, we want to examine whether the WAI can predict absenteeism beyond the existing POHS data. Therefore, we conducted a stepwise logistic regression analysis, with the WAI entered in the last step.

Table 8 - Results of a stepwise logistic regression analysis: Odd's ratios and (confidence intervals)

\begin{tabular}{|c|c|c|c|c|c|}
\hline & Step 1 & Step 2 & Step 3 & Step 4 & Step 5 \\
\hline Age & $\begin{array}{c}1.04 * \\
(1.03-1.04)\end{array}$ & $\begin{array}{c}1.04 * \\
(1.03-1.04)\end{array}$ & $\begin{array}{c}1.04 * \\
(1.03-1.04)\end{array}$ & $\begin{array}{c}1.03 * \\
(1.03-1.04)\end{array}$ & $\begin{array}{c}1.03 * \\
(1.02-1.03)\end{array}$ \\
\hline $\begin{array}{l}\text { Job Category } \\
\text { (Blue collar) }\end{array}$ & $\begin{array}{c}2.22 * \\
(1.88-2.61) \\
\end{array}$ & $\begin{array}{c}2.14 * \\
(1.81-2.52) \\
\end{array}$ & $\begin{array}{c}1.74 * \\
(1.45-2.10)\end{array}$ & $\begin{array}{c}1.80 * \\
(1.49-2.17) \\
\end{array}$ & $\begin{array}{c}1.73 * \\
(1.43-2.09)\end{array}$ \\
\hline Alcohol (Y) & & $\begin{array}{c}1.02 \\
(0.90-1.15)\end{array}$ & $\begin{array}{c}1.03 \\
(0.91-1.16)\end{array}$ & $\begin{array}{c}1.01 \\
(0.90-1.15)\end{array}$ & $\begin{array}{c}1.03 \\
(0.91-1.16) \\
\end{array}$ \\
\hline Smoking $(\mathrm{Y})$ & & $\begin{array}{c}1.17^{*} \\
(1.04-1.33)\end{array}$ & $\begin{array}{c}1.15^{*} \\
(1.01-1.30)\end{array}$ & $\begin{array}{c}1.11 \\
(0.98-1.26)\end{array}$ & $\begin{array}{c}1.12 \\
(0.99-1.28)\end{array}$ \\
\hline Exercise $(\mathrm{N})$ & & $\begin{array}{c}1.10 \\
(0.98-1.25 \\
\end{array}$ & $\begin{array}{c}1.11 \\
(0.98-1.25 \\
\end{array}$ & $\begin{array}{c}1.11 \\
(0.98-1.25)\end{array}$ & $\begin{array}{c}1.11 \\
(0.98-1.25) \\
\end{array}$ \\
\hline Fit $(\mathrm{N})$ & & $\begin{array}{c}1.00 \\
(0.87-1.16) \\
\end{array}$ & $\begin{array}{c}0.98 \\
(0.85-1.14) \\
\end{array}$ & $\begin{array}{c}0.99 \\
(0.86-11.15) \\
\end{array}$ & $\begin{array}{c}1.00 \\
(0.86-1.16) \\
\end{array}$ \\
\hline Lifting, pushing $(\mathrm{Y})$ & & & $\begin{array}{c}1.05 \\
(0.91-1.21)\end{array}$ & $\begin{array}{c}1.03 \\
(0.89-1.19) \\
\end{array}$ & $\begin{array}{c}1.01 \\
(0.88-1.17) \\
\end{array}$ \\
\hline Awkward postures (Y) & & & $\begin{array}{c}1.20 * \\
(1.03-1.41)\end{array}$ & $\begin{array}{c}1.13 \\
(0.96-1.33)\end{array}$ & $\begin{array}{c}1.09 \\
(0.92-1.28)\end{array}$ \\
\hline Static workload (Y) & & & $\begin{array}{c}1.23 * \\
(1.06-1.42)\end{array}$ & $\begin{array}{c}1.13 \\
(0.98-1.31) \\
\end{array}$ & $\begin{array}{c}1.08 \\
(0.93-1.25) \\
\end{array}$ \\
\hline Whole body vibrations (Y) & & & $\begin{array}{c}0.92 \\
(0.74-1.14)\end{array}$ & $\begin{array}{c}0.91 \\
(0.73-1.12)\end{array}$ & $\begin{array}{c}0.92 \\
(0.74-1.14)\end{array}$ \\
\hline Hand-arm vibrations (Y) & & & $\begin{array}{c}1.18 \\
(0.96-1.44)\end{array}$ & $\begin{array}{c}1.14 \\
(0.93-1.40)\end{array}$ & $\begin{array}{c}1.12 \\
(0.91-1.38)\end{array}$ \\
\hline Repetitive movements (Y) & & & $\begin{array}{c}1.08 \\
(0.92-1.27)\end{array}$ & $\begin{array}{c}1.02 \\
(0.86-1.20)\end{array}$ & $\begin{array}{c}0.98 \\
(0.83-1.16) \\
\end{array}$ \\
\hline Work pressure $(\mathrm{Y})$ & & & $\begin{array}{c}1.01 \\
(0.89-1.15)\end{array}$ & $\begin{array}{c}0.96 \\
(0.84-1.08) \\
\end{array}$ & $\begin{array}{c}0.97 \\
(0.85-1.10)\end{array}$ \\
\hline Autonomy (N) & & & $\begin{array}{c}1.22 * \\
(1.08-1.38) \\
\end{array}$ & $\begin{array}{c}1.19 * \\
(1.05-1.35) \\
\end{array}$ & $\begin{array}{c}1.18 * \\
(1.04-1.34) \\
\end{array}$ \\
\hline Social Support (N) & & & $\begin{array}{c}1.03 \\
(0.87-1.22) \\
\end{array}$ & $\begin{array}{c}0.92 \\
(0.77-1.10) \\
\end{array}$ & $\begin{array}{c}0.90 \\
(0.75-1.07) \\
\end{array}$ \\
\hline Musculoskeletal complaints (Y) & & & & $\begin{array}{c}1.41 * \\
(1.22-1.64)\end{array}$ & $\begin{array}{c}1.26 * \\
(1.08-1.46)\end{array}$ \\
\hline Chest pain (Y) & & & & $\begin{array}{c}1.07 \\
(0.88-1.31)\end{array}$ & $\begin{array}{c}1.05 \\
(0.85-1.25)\end{array}$ \\
\hline Lung complaints (Y) & & & & $\begin{array}{c}1.22 * \\
(1.02-1.46)\end{array}$ & $\begin{array}{c}1.14 \\
(0.95-1.36) \\
\end{array}$ \\
\hline Stress (Y) & & & & $\begin{array}{c}1.16 * \\
(1.01-1.34) \\
\end{array}$ & $\begin{array}{c}1.06 \\
(0.92-1.23) \\
\end{array}$ \\
\hline Depressive complaints (Y) & & & & $\begin{array}{c}1.11 \\
(0.90-1.38) \\
\end{array}$ & $\begin{array}{c}1.06 \\
(0.85-1.31) \\
\end{array}$ \\
\hline $\begin{array}{l}\text { WAI (Excellent) } \\
\text { WAI (Good) } \\
\text { WAI (Moderate) } \\
\text { WAI (Poor) }\end{array}$ & & & & & $\begin{array}{c}1.00 \\
1.60 * \\
(1.36-1.88) \\
2.27 * \\
(1.85-2.78) \\
1.92 * \\
(1.31-282) \\
\end{array}$ \\
\hline $\mathbf{R}^{2}$ & $5 \%$ & $5 \%$ & $7 \%$ & $8 \%$ & $9 \%$ \\
\hline
\end{tabular}


Results in table 7 show that many of the factors are related to absenteeism. However, in a stepwise logistic regression analysis, most of them become insignificant. In the last step (Step 5), only age; job category; autonomy; having musculoskeletal complaints; and the Work Ability Index measured in 2005 remain significantly associated with long-term absenteeism in the 4 years following the health exam. Compared

\section{Conclusion}

Construction industry consists of many jobs that are characterized by physically demanding jobs, which in turn is related to a high percentage of musculoskeletal disorders, reduced work ability, a high number of injuries, high absenteeism from work and high disability. If we would be able to identify and monitor workers who have a high chance to develop injuries and diseases and the associated absenteeism, we could take preventive action. We are especially interested in long-term absenteeism, because the literature shows that the chance of a construction workers returning to his job after a period of long-term absenteeism is very small [5].

The purpose of this study was to examine whether the Work Ability Index (WAI) is a good instrument to predict long-term absenteeism. Since 2005 the WAI is part of the standardized routine health examination for construction workers in The Netherlands. Results of this study show that the WAI does predict long-term absenteeism better than many other variables such as life style characteristics, job characteristics and health complaints, including objective assessment of these health complaints (COPD) and risk of future complaints (cardiac events). The latter is interesting because collecting physical data is the most expensive part of a physical health exam.

Not surprisingly, additional analysis of the different aspects of the WAI (see table 1) show that selfreported absenteeism in the past year is the best predictor of future absenteeism. The other important predictors are self-reported workability and current medical symptoms, conditions, and injuries

Results of our analysis show that -apart from the WAI- only age, job category (blue collar vs. white collar), lack of autonomy, and musculoskeletal disorders predict long-term absenteeism.

However, results also show that only about $10 \%$ of variance in long-term absenteeism is explained by these variables. These results support earlier research with respondents with an excellent WAI score, respondents with a poor WAI score have nearly a two time (1.92) higher chance to report long-term absenteeism in the 4 years following the survey; respondents with a moderate WAI score a more than 2 times higher chance (2.27); and respondents with a good WAI about 1.6 times higher chance to report longterm absenteeism.

on absenteeism in construction industry [6], using another questionnaire and another sample. That raises the question how much of future absenteeism can be explained. As mentioned in the Methods section, days-away-from-work does not only consist of workrelated absenteeism. It also contains absenteeism caused by accidents and injuries in private life. This is the result of Collective Bargaining Agreements in the 1960s and it avoids the problems arising from having to determine the work-relatedness of absenteeism. Unfortunately it is therefore not possible to make a distinction between work-related causes of absenteeism and causes in the private situation.

Still, even if the Work Ability Index is not the most ideal instrument to predict absenteeism in The Netherlands, it can be used for early identification of people at risk and take prevention action in order to avoid long-term absenteeism and disability [7].

\section{Acknowledgements}

This research was made possible with a grant from the Arbouw Foundation.

\section{References}

[1] J. Liira, et al., "Work ability of middle-aged Finnish construction workers: A follow-up study in 1991-1995," International Journal of Industrial Ergonomics, vol. 25, pp. 477-481, 2000.

[2] P. Leino, et al., "Working Conditions, Health and Need for Rehabilitation of Workers in Short Term Contract (LEL) Occupations," LEL Pension Fund Publications, Heslinki, Finland1991.

[3] J. Ilmarinen, et al., "Changes in work ability of active employees over an 11-year period," Scandinavian Journal of Work and Environmental Health, vol. 23, pp. 49-57, 1997.

[4] P. L. T. Hoonakker and J. C. van Duivenbooden, "Monitoring working conditions and health of older workers in Dutch construction industry," American Journal of Industrial Medicine, vol. 53, pp. 641-653, 2010.

[5] A. Ploeger, "Arbeidsongeschiktheid in de bouw [Disability in the construction industry]," Economic Institute for the Construction Industry, Amsterdam, The Netherlands, 2001. 
[6] P. L. T. Hoonakker, et al., "The relation between experienced workload, working conditions, health and absenteeism in construction industry," in $O D A M$, Den Haag, 1998, pp. 683688.

[7] A. Burdorf, et al., "Development of a decision model to identify workers at risk for long-term disability in the construction industry," Scand J Work Environ Health, vol. 31, pp. 31-36, 2005. 